\title{
OVARIAN ECTOPIC PREGNANCY WITH IUCD IN SITU- A RARE CASE REPORT
}

\author{
Shweta Gupta1, Kajal Kunwar², Mukta Agrawal', Nimisha Agrawal', Ankita Mani ${ }^{5}$
}

${ }_{1}^{1}$ Senior Resident, Department of Obstetrics and Gynaecology, All India Institute of Medical Sciences, Patna, Bihar, India ${ }^{2}$ Senior Resident, Department of Obstetrics and Gynaecology, All India Institute of Medical Sciences, Patna, Bihar, India. ${ }^{3}$ Associate Professor, Department of Obstetrics and Gynaecology, All India Institute of Medical Sciences, Patna, Bihar, India. ${ }^{4}$ Assistant Professor, Department of Obstetrics and Gynaecology, All India Institute of Medical Sciences, Patna, Bihar, India. ${ }^{5}$ Senior Resident, Department of Obstetrics and Gynaecology, All India Institute of Medical Sciences, Patna, Bihar, India.

HOW TO CITE THIS ARTICLE: Gupta S, Kunwar K, Agrawal M, et al. Ovarian ectopic pregnancy with IUCD in situ- a rare case report. J. Evolution Med. Dent. Sci. 2018;7(45):4926-4928, DOI: 10.14260/jemds/2018/1096

\section{PRESENTATION OF CASE}

Ovarian pregnancy is a very rare form of ectopic pregnancy.(1) It was first described in $17^{\text {th }}$ century by Dr. Saint Monnissey. Incidence has been estimated around $0.5-3 \%$ of all ectopic pregnancies.(2) Incidence has increased in recent years due to increase in diagnosis which can be attributed to availability of USG facility, more sensitive $\beta$-hCG assay, diagnostic laparoscopy and risk factors associated with overall ectopic pregnancies. Use of IUCD has been disproportionately associated with primary ovarian pregnancy with incidence range being 57 - 90\%.(3-7) Diagnosis is done by both surgical and histopathological observations.(8) Usually, it ends in rupture in early stage.(9) Classical management is surgicalwedge resection or oophorectomy. Medical management has been reported to be successful in few cases.

\section{CLINICAL DIAGNOSIS}

A 22 years old female P2L2 came in OPD with chief complaints of overdue menses for 23 days and mild pain lower abdomen since 7 days. She was hepatitis B + with history of IUCD application 2 years back and was found urine pregnancy test +. General examination was fair with normal vital parameters. On per abdomen, abdomen was soft and non-tender. On per speculum IUCD thread was visible and on per vaginal examination uterus was bulky soft with left adnexal mass of approximately $3-4 \mathrm{~cm}$.

\section{DIFFERENTIAL DIAGNOSIS}

1. Tubal ectopic pregnancy

2. Incomplete abortion

3. Ruptured corpus luteal cyst

4. Germ cell tumours of ovary.

\section{PATHOLOGICAL DISCUSSION}

On USG, uterus was $8 \times 3 \mathrm{~cm}$ with IUCD in situ. Left ovary contained a gestational sac like structure of $1.2 \mathrm{~cm}$ ( 6 weeks, 4 days) with a foetal pole of CRL - 6 weeks 2 days and foetal cardiac activity was present. There was increased vascularity around gestational sac. Right ovary was $2.2 \times 1.7 \mathrm{~cm}$.

All her routine investigations were within normal limits with $\mathrm{Hb} 11.2 \mathrm{~g} / \mathrm{dL}$. $\beta$-hCG was $181.80 \mathrm{mIU} / \mathrm{mL}$. She was

'Financial or Other Competing Interest': None.

Submission 21-09-2018, Peer Review 16-10-2018,

Acceptance 25-10-2018, Published 05-11-2018.

Corresponding Author:

Dr. Shweta Gupta,

\#502, Shiv-Shakti Palace,

Near Colony More, Kankarbagh Main Road,

Tatna-800020, Bihar, India.

E-mail: drshweta191@gmail.com

DOI: $10.14260 /$ jemds/2018/1096

(c) $($ ) $\ominus$ planned for medical management single dose Inj. methotrexate $75 \mathrm{mg}$ IM. On day 4, $\beta$-hCG $20331 \mathrm{mIU} / \mathrm{mL}$ and patient developed severe pain abdomen on left iliac fossa with normal vitals. Then patient was taken for Laparotomy. Around $200 \mathrm{~mL}$ of blood was seen intraperitoneally. There was ruptured left ovary with intact gestational sac in process of expulsion. Primary ovarian pregnancy was confirmed according to Spigelberg's four criteria: - 1. Intact fallopian tube on affected side; 2 . Gestational sac should occupy the position of ovary on affected side; 3. Gestational sac should be connected to uterus by utero-ovarian ligament; 4. Ovarian tissue must be located in gestational sac wall.(10) On HPE, ovarian pregnancy confirmed and endometrial tissue showed features of secretory endometrial glands with decidualised stroma.
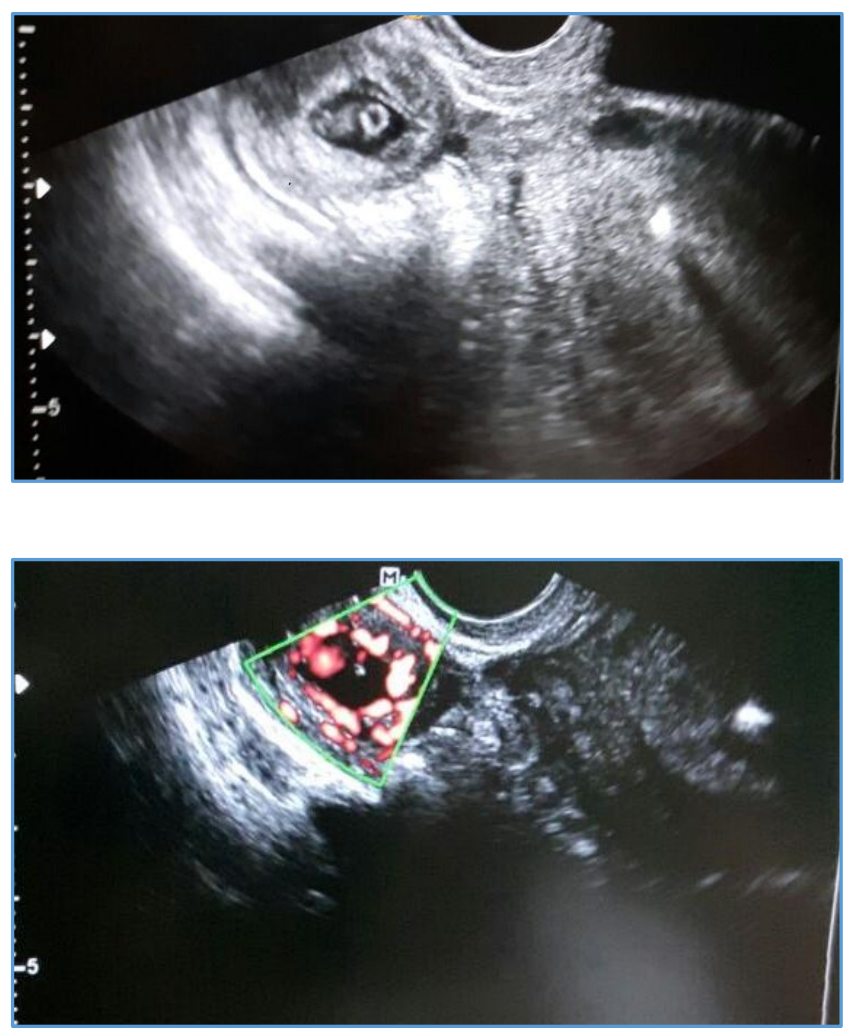

Figure 1. TVS with Colour Doppler showing Ring of Fire Pattern in Ovary with Alive Embryo 


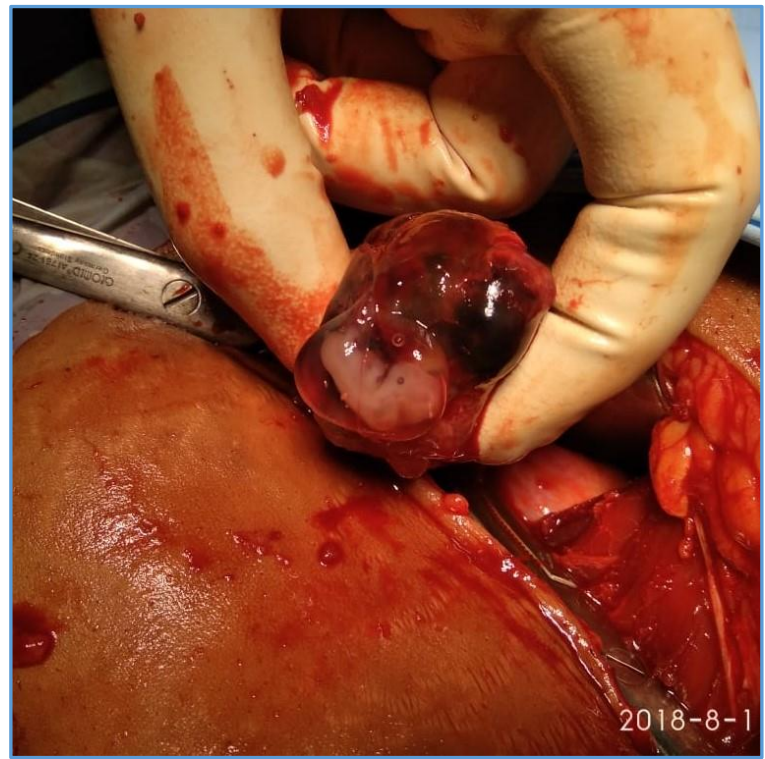

Figure 2. Intra-operative Picture showing Gestational Sac with Embryo

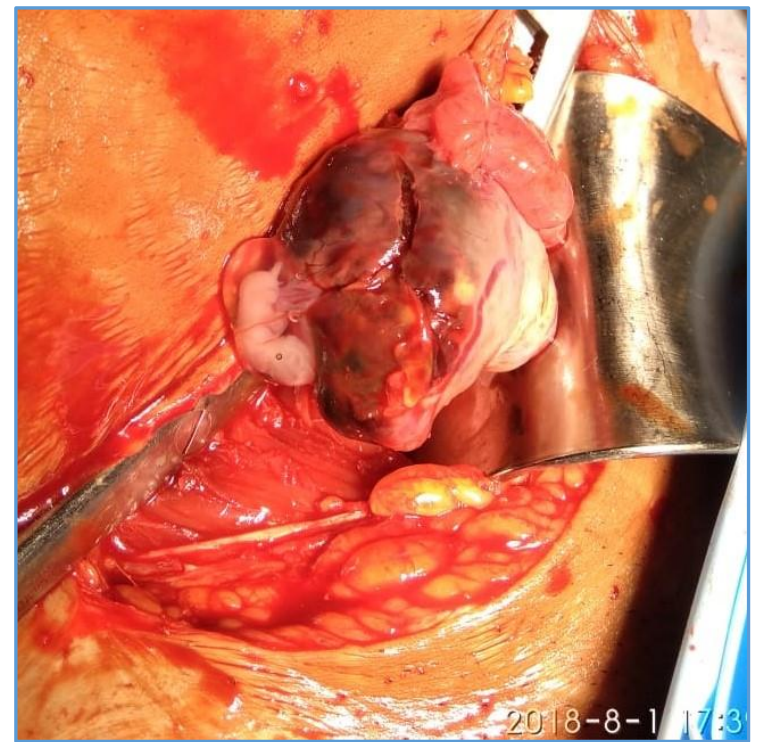

Figure 3. Intra-operative Picture showing Rupture in Ovary with Gestational Sac Hanging through the Rent

\section{DISCUSSION OF MANAGEMENT}

An ectopic pregnancy is characterised by implantation and development of embryo outside uterine cavity. Ovarian ectopic pregnancy incidence after natural conception ranges from 1 in 2000 to 1 in 60,000 deliveries and accounts for $3 \%$ of all ectopic pregnancies.(8) Poor clinical symptomatology and difficult USG assessment makes its preoperative diagnosis difficult. Berger and Blechner documented that the ratio of ovarian ectopic pregnancy among women using an IUD to all ectopic cases is 1: 9; its prevalence in the general population is detected as 1: 150 to 200.(11) In our case too IUCD was in situ. It is believed that IUCDs trigger mild inflammation that disturbs the ciliary activity of the endosalpinx and leads to ovum transport delay and ectopic implantation.(11)

Most common presenting symptoms include amenorrhoea, abdominal pain and vaginal bleeding like other ectopic gestations. In our case there was history of amenorrhoea and mild pain in lower abdomen on left side. On examination, an adnexal mass may be palpable in $60 \%$ of cases. In our case, on examination there was mild tenderness in left iliac fossa and on per vaginal examination cervical motion tenderness was present with left adnexal tenderness.

Early diagnosis and treatment are very crucial for ectopic pregnancies that stands true for ovarian ectopic too, as it usually terminates by rupture in the first trimester leading to internal haemorrhage and hypovolemic shock status. There are reports of ovarian pregnancy continuing beyond and giving live birth.(12) Evaluation of beta-HCG together with transvaginal USG is very important for early diagnosis.(13)

Management is mostly surgical either by wedge resection or ovariectomy. In recent years medical and conservative treatments have also been tried successfully to prevent ovarian tissue loss, pelvic adhesions and to preserve the patient's fertility. These include administration of mifepristone, parenteral prostaglandin F2 $\alpha$ and methotrexate treatment for non-ruptured cases detected with USG or laparoscopy.(14-19) In our case also we tried first medical management, but due to rupture we had to opt for more radical approach. The Royal College of Obstetricians and Gynaecologists recommends that women with ectopic pregnancy most suitable for methotrexate therapy are those with serum beta-HCG levels of $3000 \mathrm{IU} / \mathrm{mL}$ and with minimum symptoms (RCOG, 2001).

In the era of artificial reproductive techniques, ectopic pregnancies are not uncommon. Ovarian ectopic pregnancies have posed challenges in early pre-operative diagnosis due to subtle clinical findings and difficult USG interpretation. Though, surgery is the definitive management, but more conservative approaches are still being tried with promising results. Our chief goal is to obtain early pre-operative diagnosis with successful medical management.

\section{FINAL DIAGNOSIS}

Ovarian Ectopic Pregnancy with IUCD In Situ.

\author{
Abbreviations \\ IUCD- Intrauterine Contraceptive Devices \\ USG- Ultrasonography \\ OPD- Outpatient Department \\ HPE- Histopathology \\ HCG- Human Chorionic Gonadotropin \\ CRL- Crown-Rump Length \\ IM- Intramuscular
}

\section{REFERENCES}

[1] Fritz MA, Speroff L. Clinical gynecologic endocrinology and infertility. $8^{\text {th }}$ edn. Philadelphia: Lippincott Williams and Wilkins 2011: p. 1409.

[2] Grimes HG, Nosal RA, Gallagher JC. Ovarian pregnancy: a series of 24 cases. Obstet Gynecol 1983;61(2):174-80.

[3] Ercal T, Cinar 0, Mumcu A, et al. Ovarian pregnancy; relationship to an intrauterine device. Aust N Z J Obstet Gynaecol 1997;37(3):362-4.

[4] Bouyer J, Rachou E, Germain E, et al. Risk factors for extrauterine pregnancy in women using an intrauterine device. Fertil Steril 2000;74(5):899-908.

[5] Comstock C, Huston K, Lee W. The ultrasonographic appearance of ovarian ectopic pregnancies. Obstet Gynecol 2005;105(1):42-5. 
[6] Raziel A, Golan A, Pansky M, et al. Ovarian pregnancy: a report of twenty cases in one institution. Am J Obstet Gynecol 1990;163(4 Pt 1):1182-5.

[7] Cabero A, Laso E, Lain JM, et al. Increasing incidence of ovarian pregnancy. Eur J Obstet Gynecol Reprod Biol 1989;31(3):227-32.

[8] Scutiero G, Di Gioia P, Spada A, et al. Primary ovarian pregnancy and its management. JSLS 2012;16(3):4924.

[9] Cunningham FG, Leveno KJ, Bloom SL, et al. Ectopic pregnancy. William's obstetrics. 23rd edn. McGraw-Hill 2010: p. 251.

[10] Spigelberg 0. Casusistik der ovarialschwangerschaft. Arch Gynecol 1878;13:73.

[11] Berger B, Blechner JN. Ovarian pregnancy associated with copper-7 intrauterine device. Obstetr Gynecol 1978;52(5):597-600.

[12] Chang FW, Chen CH, Liu JY. Early diagnosis of ovarian pregnancy by ultrasound. Int J Gynaecol Obstet 2004;85(2):186-7.

[13] Phupong V, Ultchaswadi P. Primary ovarian pregnancy. J Med Assoc Thai 2005;88(4):527-9.
[14] Levin JH, Lacarra M, d'Ablaing G, et al. Mifepristone (RU 486) failure in an ovarian heterotopic pregnancy. Am J Obstet Gynecol 1990;163(2):543-4.

[15] Shamma FN, Schwartz LB. Primary ovarian pregnancy successfully treated with methotrexate. Am J Obstet Gynecol 1992;167(5):1307-8.

[16] Pagidas K, Frishman GN. Nonsurgical management of primary ovarian pregnancy with transvaginal ultrasound-guided local administration of methotrexate. J Minim Invasive Gynecol 2013;20(2):252-4.

[17] Di Luigi G, Patacchiola F, La Posta V, et al. Early ovarian pregnancy diagnosed by ultrasound and successfully treated with multidose methotrexate. A case report. Clin Exp Obstet Gynecol 2012;39(3):390-3.

[18] Chelmow D, Gates E, Penzias AS. Laparoscopic diagnosis and methotrexate treatment of an ovarian pregnancy: a case report. Fertil Steril 1994;62(4):87981.

[19] Annunziata N, Malignino E, Zarcone R. Ovarian pregnancies treated with methotrexate. Panminerva Med 1996;38(3):190-2. 